Muséologies

Les cahiers d'études supérieures

muséologies

\title{
Multicultural Art Education Through and With Contemporary Art: Positioning the Contemporary Art Museum as a Leader in Generating Critical Dialogues
}

\section{Natasha S. Reid}

Volume 7, numéro 1, 2014

Le dialogue dans les musées d'art contemporain

URI : https://id.erudit.org/iderudit/1026648ar

DOI : https://doi.org/10.7202/1026648ar

Aller au sommaire du numéro

Éditeur(s)

Association Québécoise de Promotion des Recherches Étudiantes en

Muséologie (AQPREM)

ISSN

1718-5181 (imprimé)

1929-7815 (numérique)

Découvrir la revue

Citer cet article

Reid, N. S. (2014). Multicultural Art Education Through and With

Contemporary Art: Positioning the Contemporary Art Museum as a Leader in

Generating Critical Dialogues. Muséologies, 7(1), 81-100.

https://doi.org/10.7202/1026648ar

Tous droits réservés (C) Association Québécoise de Promotion des Recherches Étudiantes en Muséologie (AQPREM), 2014
Ce document est protégé par la loi sur le droit d'auteur. L'utilisation des services d'Érudit (y compris la reproduction) est assujettie à sa politique d'utilisation que vous pouvez consulter en ligne.

https://apropos.erudit.org/fr/usagers/politique-dutilisation/ 
Article trois

\section{Multicultural Art Education Through} and With Contemporary Art: Positioning the Contemporary Art Museum as a Leader in Generating Critical Dialogues

Natasha S. Reid 
Natasha S. Reid is an Assistant Professor in the School of Art at the University of Arizona, where she teaches courses in art and visual culture education and art museum education. She received her doctorate in Art Education from Concordia University in 2012. Natasha was the 2013 recipient of the National Art Education Association's Elliot Eisner Doctoral Research Award in Art Education, which she received for her research into the personal and professional identities of museum educators. She was also the 2013 recipient of the Governor General's Gold Medal at Concordia University. From 2012 to 2013, Natasha was a Fonds de recherche du Québec Société et culture Postdoctoral Research Fellow who worked with New York University and the Université du Québec à Montréal. Natasha was the Assistant Editor for the Canadian Review of Art Education from 2007 to 2011. She has worked with various galleries, museums, and community centres in Canada and the United States. nsreid@email.arizona.edu 


\section{The Potential for Multicultural Art Education in Contemporary Art Museums}

Multicultural education is an expanding field with an impressive collection of literature ${ }^{1}$. Art educators who employ critical approaches to multicultural education examine the complexities associated with race and culture with their students through artistic explorations ${ }^{2}$. These educators acknowledge how art education can and should offer students opportunities to become involved in dynamic dialogues, learn critical thinking skills, engage in empathic understanding, envision creative solutions, and participate in social action. They view art as a powerful tool for change and believe that the art classroom must become a dynamic, politicized location rather than a neutral, apolitical 'haven'. Their quest is a challenging one during this time of standardized tests, narrowing resources, reduction of visual arts classes in schools, and debates about art and social concerns.

Within this climate, art museums have the potential to become essential resources in multicultural art education, as they are alternative sites for learning that are often considered to be important locations for examining cultures. In an effort to promote the development of less elitist and more socially-responsive museum institutions, the museum world has increasingly become concerned with issues of "equality, diversity, social justice and human rights", issues which are integral components of multicultural educational efforts ${ }^{3}$. This is seen in areas such as curatorial practices, public access and inclusion measures, outreach

1 BALLENGEE-MORRIS, Christine and Patricia, L. STUHR, "Multicultural art and visual cultural education in a changing world". Art Education. vol. 54, no. 4, 2001, pp. 6-13; CAHAN, Susan E. and Zoya KOCUR. "Contemporary art and multicultural education”. In. JOO, Eungie and Joseph KEEHN II with Jenny HAM-ROBERTS (Eds.). Rethinking contemporary art and multicultural education. New York and London: Routledge in association with The New Museum of Contemporary Art, 2011, pp. 3-16; CHALMERS, Graeme, F. "Celebrating pluralism six years later: Visual transculture/s, education, and critical multiculturalism”. Studies in Art Education. vol. 43, no. 4, 2002, pp. 293306; DESAI, Dipti. "Places to go: Challenges to multicultural initiatives, educational programming, public programming, hiring practices, policy creation, and professional development.

For example, in June 2013, the Corcoran Gallery of Art, in Washington, D.C., held a four-day professional development session for K-12 teachers titled Art and Social Justice. I was invited to give the keynote address and lead a full-day workshop dedicated to examining the connections between art and social justice issues, particularly in relation to critical multicultural education practices in museums. Pedagogical methods for engaging youth in critical discussions and actions related to multiculturalism through art and art museums were central to this session ${ }^{4}$. Educators from a wide variety of fields were engaged in a series of activities within the museum that offered insight into how they can employ art and art museums as tools for examining crucial social and political issues with their students and for initiating positive action. Another example is the New Museum of Contemporary Art's (New Museum) Global Classroom (G:Class), which is an educational program for high school students. This program employs contemporary art as a tool for encouraging critical and creative skills and visual and cultural literacy. $\mathrm{G}$ :Class is grounded in social issues that affect the lives of these students. The case study explored later in this article showcases one of the G:Class's projects.

Contemporary art museums, such as the aforementioned New Museum, are particularly well positioned to engage in critical multicultural education since many contemporary artists are exploring issues pertaining to equality, diversity,

art education in a global economy". Studies in Art Education. vol. 46, no. 4, 2005, pp. 293-308.

2 Ibid.(DESAI).

3 NIGHTINGALE, Eithne and Richard SANDELL. "Introduction". In. NIGHTINGALE, Eithne and Richard SANDELL (Eds.). Museums, equality and social justice. London \& New York: Routledge, 2012, p. 1.

4 Corcoran Gallery of Art. Educator Programs. <http:// www.corcoran.org/educators-students/educators/educator-programs> (retrieved in May, 2013). 
and social justice, all of which are important tenets of critical multicultural education. For the past twenty years or so, we have seen a marked increase in artists who are working with "issues of social and environmental responsibility, and of multiculturalism, or 'parallel' cultures, rather than a dominant monoculturalism" . Examples of such artists and their work include: Yinka Shonibare's explorations of hybrid cultural identities and postcolonial realities; Kehinde Wiley's paintings of urban youth in heroic stances, which challenge stereotypes; Carrie Mae Weem's photographic series, Ain't Jokin', which requires viewers to confront a series of racist slurs, jokes, and generalizations; Fred Wilson's Mining the Museum, which juxtaposes objects from the Maryland Historical Society's collection in order to expose institutional racism and offer counter-narratives; and Annie Pootoogook's drawings of contemporary Inuit daily life that push against the typical vision of an untouched North. This is but a small sampling of the multitude of artists who are employing a wide variety of tools to critique and provoke dialogues concerning critical approaches to multiculturalism through their $\operatorname{art}^{6}$. This art can be employed as a pedagogical site "that suggests alternative ways of thinking about the past, present and the future" ${ }^{\text {" }}$. As such, contemporary art can become a powerful platform for engaging in critical approaches to multicultural education.

Thus, because of the nature of the contemporary art museum's artistic collections and because of the turn towards socially responsive approaches in the museum world, the contemporary art museum is naturally positioned to become a leader and essential resource in the field of multicultural art education. Yet there is little research into the unique position of contemporary art museums in relation to critical multicultural concerns, and there is scant literature offering examples of contemporary

5 GABLIK, Suzi. The reenchantment of art. New York: Thames and Hudson, 1991, p. 4.

6 DESAI, Dipti. "Reflections on social justice art teacher education”. In. ANDERSON, Tom et al. (Eds.). Art education for social justice. Reston, VA: NAEA, 2010, p. 176. art museums that are using this pedagogical approach. This article responds to this gap by investigating the important role that contemporary art museums can take in efforts to promote multicultural art education. The article investigates one project from a contemporary art museum that is working with elements of critical multiculturalism in their educational programming. This project is the What We Want, What We Believe mural, which evolved out of the Emory Douglas Black Panther exhibit at the New Museum in 2009. Through analyzing this case study, the article responds to the following primary question: How can educational programming in contemporary art museums reflect, support, and contribute to critical multicultural approaches explored in the field of art education and contemporary artistic practices? The case study example will demonstrate how the museum's role in facilitating dynamic dialogues between audiences and contemporary artists, between audiences and local communities, and between audience members themselves can assist in this effort.

\section{Multicultural Art Education: Definitions, Challenges, and the Place of Contemporary Art}

Multicultural education grew out of the social activism of the 1960s and 1970s. At its core, multicultural education aims to "change the power structure in the wider society in order to foster social and political empowerment for all students" ${ }^{8}$. In its essence, multicultural education promotes equality, diversity, inclusivity, and justice by engaging students in dynamic critical dialogues with diverse community members and by promoting action. As such, multicultural education is intimately related to social justice efforts. Educational researcher Christine Sleeter outlined the importance that equality and justice should take in multicultural

\footnotetext{
7 DESAI, Dipti et al.. History as Art, Art as History: Contemporary art and social studies education. London and New York: Routledge, 2010, p. 7.

8 CAHAN, Susan E. and Zoya KOCUR. "Contemporary art and multicultural education”. In. JOO, op. cit., p. 5.
} 
education: "Justice, equality, dignity, and self-determination: these ideals should be the centrepiece of multicultural education" $"$.

The visual arts offer ideal locations for examining the aforementioned ideals and for developing alternative and complex understandings of race, ethnicity, and culture. As Bailey and Desai have noted: "Like multicultural education, art is often used to shift or challenge people's understanding about particular social issues and/or historical events and, in doing so, make visible issues facing different social groups in our society" ${ }^{10}$. This is especially true of contemporary art. In 1991, Suzi Gablik predicted that the next few decades would see a proliferation of "art that is essentially social and purposeful, art that rejects the myths of neutrality and autonomy"11. Gablik's prediction was accurate; we have seen an increasing number of contemporary artists who are working with critically engaged practices and who feature alternative readings to typically "monolithic and homogeneous views of history"12. Many of these artists pose critical questions about race and culture, which instigate dynamic dialogues and challenge repressive and discriminatory power structures.

Philosopher and activist Cornel West coined the term "politics of difference" to describe the practices of artists, art critics, and art theorists who are aiming to "empower and enable social action and, if possible, to enlist collective insurgency for the expansion of freedom, democracy and individuality" ${ }^{13}$. These artists, theorists, and critics are working with

9 SLEETER, Christine. "Foreword". In CAHAN, Susan E. and Zoya KOCUR (Eds.). Contemporary art and multicultural education. New York: The New Museum of Contemporary Art; London: Routledge, 1996, p. xvi.

10 BAILEY, Chelsea and Dipti DESAI. "Visual art and education: Engaged visions of history and community". Multicultural Perspectives. vol. 7, no. 1, 2005, p. 40.

11 GABLIK, op. cit., p. 4.

12 CAHAN, Susan E. and Zoya KOCUR. "Contemporary art and multicultural education”. In. JOO, op. cit., p. 9. 13 WEST, Cornel. "The new cultural politics of difference”. In. FERGUSON, Russell et al. (Eds.). Out there: Marginalization and contemporary cultures. New York: The New Museum of Contemporary Art and Massachusetts Institute of Technology, 1990, pp. 19-20. context and plurality as opposed to promoting generalized, decontextualized, and uniform views. They are gravitating toward art that is "specifically concerned with the ways in which power functions in relation to identity and social practices" 14 . The artists mentioned in the introduction of this article are fine examples of individuals working within this realm. These and a plethora of other contemporary artists are aware that art can be a particularly effective medium to spark meaning-making and understanding in relation to critical multiculturalism. Their art is influencing art educators and students working with critical approaches to multicultural art education. For example, art educator and researcher Karen Keifer-Boyd employed the work of Fred Wilson as a starting point for her "politics of display" project, which asked pre-service art teachers to chose a museum on the internet and alter the meanings of "art, artist, museum, audience, and art education" by using Photoshop and HyperStudio to rework the virtual spaces of these museums ${ }^{15}$. Another example is found in Tom Anderson and Melody Milbrandt's social reconstructionist art education book, Art for Life: Authentic Instruction in Art ${ }^{16}$. This widely used art education resource examines methods for employing art as a tool for exploring a variety of social justice issues, including multicultural concerns. In this book, nearly all of the artists the authors cover are contemporary artists working with social justice issues. Following Cahan and Kocur, I believe that " $[\mathrm{t}]$ he relevance of contemporary art to multicultural education cannot be overstated"17.

14 BAILEY, Chelsea and Dipti DESAI. "Visual art and education: Engaged visions of history and community”. Multicultural Perspectives. vol. 7, no. 1, p. 39, 2005, p. 39.

15 GARBER, Elizabeth. "Social justice art education". Visual Arts Research. vol. 30, no. 2, p. 8.

16 ANDERSON, Tom and Melody K. MILBRANDT. Art for life: Authentic instruction in art. New York: McGraw-Hill, 2005.

17 CAHAN, Susan E. and Zoya KOCUR. "Contemporary art and multicultural Education”. In. JOO, op. cit., p. 9. 
Unfortunately, many educators are hesitant to incorporate contemporary art and critical approaches to multicultural art education into their teaching ${ }^{18}$. It is not uncommon for art teachers, and people in general, to feel more comfortable with so-called 'attractive' representational art that has come to be seen as traditional $\operatorname{art}^{19}$. This is typically because they feel they do not have the knowledge and tools required to engage with contemporary art, which often contains innovative media and complex, socially engaged topics that can spark conversations about contentious issues ${ }^{20}$. The standard art featured in curriculum materials for teachers tends to focus on traditional art that has "withstood the test of time" and does not open up difficult issues ${ }^{21}$. These artistic examples are often focused on Western 'masters' rather than diverse contemporary art examples grounded in critical multicultural concerns. As Elizabeth Garber noted, teachers are often drawn to teaching approaches and content that they experienced as students and pre-service teachers ${ }^{22}$. Thus, when pre-service teachers have less exposure to current art, there is a greater tendency for contemporary art practices to be marginalized within future art classrooms, which limits the potential for critical multicultural approaches to be infused into these locations.

The realities of school culture present further challenges to teachers interested in infusing contemporary art and critical multicultural education into their classes. Even if student-teachers study multicultural art education and contemporary art and become dedicated to critical inquiry and transformative pedagogy during their pre-service education, most of them do not go on to employ these practices in their classrooms ${ }^{23}$. Garber contended: "Engaging in practices of social justice can be

18 PAGE, Tara et al. "Teaching now with the living: A dialogue with teachers investigating contemporary art practices". International Journal of Art and Design Education. vol. 25, no. 2, 2006, pp. 146-155.

19 VILLENEUVE, Pat and Mary ERICKSON. "The trouble with contemporary art is...”, Art Education. vol. 61, no. 2, 2008, pp. 92-97.

20 CAHAN, Susan E. and Zoya KOCUR. "Contemporary art and multicultural education”. In. JOO, op. cit., p. 9. 21 Ibid. high risk behaviour, especially in some schools and school districts" ${ }^{24}$. Some of these locations are fearful of teachers "encouraging critique of and change in the status quo" ${ }^{25}$. Contemporary artist Lan Tuazon purports, "Consciously or not, teachers are susceptible to forms of institutionalized censorship" ${ }^{26}$. Additionally, time constraints often make it difficult for teachers to explore such social justice concerns while also encouraging art techniques. Successful engagement with multicultural art education in schools requires significant support from and even partnership with school administrations and local communities. Contemporary art museums that work with multicultural visions, programming, and pedagogies are ideal community locations for offering such support and partnership potential.

\section{The New Museum as a Community Partner: Responding to Community Needs}

In order to fully embrace their contemporary roles as socially engaged institutions, many museums are recognizing the need to offer meaningful, dialogical, and potentially transformative experiences. As examined earlier in this article, contemporary art museums have a distinct advantage in this quest, since their contents tend to naturally provoke such encounters. However, even contemporary art museums have to move beyond merely displaying art that addresses the "politics of difference" in order to realize their potential as transformative, activist-oriented, and socially engaged institutions. Contemporary art museums must actively reach out to diverse audiences and deeply engage with critical multicultural education.

22 GARBER, Elizabeth. "Teaching about gender issues in the art education classroom: Myra Sadker Day”. Studies in Art Education. vol. 45, no. 1, 2003, p. 60.

23 Id., "Social justice and art education". Visual Arts Research. vol. 30 , no. 2 , 2005, pp. 12-13.

24 Id., p. 13.

25 Ibid.

26 TUAZON, Lan. "What's in it for me?: Radical common sense in art and education.”. In JOO, op. cit., p. 28. 
There are a number of contemporary art museums in New York City that employ a multicultural vision and incorporate this into their educational endeavours. These include, but are not limited to, the Bronx Museum of Art, the Museum of Contemporary African Diasporan Art, El Museo del Barrio, the Studio Museum, and the New Museum. The New Museum's high school educational programming, G:Class, will serve as an example of critical multicultural programming in the following discussion.

In 1996, the New Museum published Contemporary Art and Multicultural Education, which became a preeminent guide for multicultural art education through the use of contemporary art in K-12 classrooms. This publication has been employed as a tool for classroom teachers for over a decade, offering them insight into how to "engage students in social analysis, examining art as a mode of communication about issues and concerns of diverse communities, and of compelling interest to young people" ${ }^{27}$. According to Marcia Tucker, the Founding Director of the Museum, "Like all of The New Museum's activities, this work has been produced by and is addressed to the multiracial, multiethnic, experientially diverse constituency that reflects the world in which we live" 28 . The publication is a reflection of the New Museum's focus on pushing boundaries, engaging in critical practices, working with diversity, and encouraging dialogue.

The editors of Contemporary Art and Multicultural Education, Susan E. Cahan and Zoya Kocur, pointed out that the project grew out of the museum's High School Art Program (HSAP), which began in 1980. The program developed collaborations with New York City public schools, particularly serving students "at risk" of academic failure ${ }^{29}$. HSAP

27 SLEETER, Christine. "Foreword". In. CAHAN, op. cit., p. xvii.

28 TUCKER, Marcia. "Preface". In. CAHAN, op. cit., p. xiv.

29 CAHAN, Susan E. and Zoya KOCUR. "Acknowledgements”. In CAHAN, op. cit., p. xi.; CAHAN, Susan E. and Zoya KOCUR. "Contemporary art and multicultural education”. In JOO, op. cit., p. 11.

30 New Museum G:Class. History. <www.gclass.org/ about/history $>$ (retrieved in February, 2013). "sought to expand the definition of art education as an interdisciplinary and culturally diverse field" and was "one of the first institutions to utilize contemporary art as a critical education tool to engage young people in multiple subject areas" ${ }^{30}$.

\section{Cahan and Kocur outlined that HSAP was} an initiative that helped to fill a lacuna in arts instruction in New York City's schools ${ }^{31}$. These authors noted that during the 1970s, the United States saw major funding reductions for the arts in public schools ${ }^{32}$. As this crisis moved into the 1980s, museums and arts organizations increasingly became key players in offering art education to public school students: "Museums, theatre groups, dance companies, orchestras, and a wide range of other arts organizations all stepped in to fill the gap left by decreased school funding, often as the sole providers of art instruction in the schools they served" ${ }^{33}$. Multicultural discourses in education, including multicultural art education, were increasing in momentum at the same time $^{34}$. As examined throughout this paper, critical multicultural art education questions power structures and aims to empower individuals to resist oppressive power in order to promote equality, diversity, and social justice. Cahan and Kocur note that there was a significant backlash against these empowering practices in schools, which led to government censorship and subsequent funding reductions that greatly affected arts institutions and schools ${ }^{35}$. For example, in 1991, the Board of Education's data revealed that two-thirds of New York City's schools did not have a licensed visual arts or music teacher ${ }^{36}$. Students in these schools were not receiving arts education from qualified specialist teachers, and were thus receiving a subpar arts education, if any arts education at all.
31 CAHAN, Susan E. and Zoya KOCUR. "Contemporary art and multicultural education”. In JOO, op.cit., pp. 3-16.

32 Ibid.

33 Id., p. 10

34 Id., pp. 3-16

35 Ibid.

36 Ibid. 
Although there were some promising increases to funding and staffing in the arts within New York City schools in the 1990s, the great struggle to maintain a significant representation of the arts in schools continued in this city and across the United States in general. The increased push for standardized testing with quantifiable results in reading, writing, and math-which was propelled by the No Child Left Behind Act of 2002-has been at the expense of other subjects, most certainly including the visual arts ${ }^{37}$. Cahan and Kocur noted that in New York City, this situation is bleakest in lower-income communities ${ }^{38}$. New York City's public schools are increasingly benefitting from arts instruction from outside arts organizations in an effort to fill this gap ${ }^{39}$. Cahan and Kocur proclaimed that as a result of this situation, "programs like the New Museum's [...] will continue to be a vital and essential component of art education in [New York City's] schools going forward" ${ }^{40}$. Such programming can support the proliferation of critical multicultural education, as the contemporary art museum offers an alternative location for students, teachers, and other community members to examine critical multicultural issues and notions in a less restrictive manner than what is often promoted in school settings.

In 2004, the New Museum transitioned to a new multicultural curriculum that added a global emphasis: the Global Classroom, or G:Class ${ }^{41}$. The G:Class' mission is three-fold:

"Encourage students' cultural literacy through contemporary art; [c] ultivate students' critical thinking, visual literacy skills, and self-expression through innovative curriculum; [u]tilize the New Museum as a cultural educational resource to expand learning beyond the classroom" ${ }^{42}$. The program accomplishes this through student seminars, professional development programs for teachers, and the G:Class website, which contains numerous

37 Ibid.

38 Ibid.

39 Ibid.

40 Id., p. 13.

41 New Museum G:Class., op. cit..

42 Ibid. lesson plans. Additionally, in 2011, the New Museum developed Rethinking Contemporary Art and Multicultural Education, which was a follow-up to their 1996 publication. The text continues the conversation begun in Contemporary Art and Multicultural Education, and builds upon the pedagogical approach of the first edition "to present new possibilities and modes of understanding art, culture, contemporaneity, and their relationships to our students and ourselves" ${ }^{43}$.

G:Class offers an example of a critical, multicultural, contemporary art museum-initiated education program for inner-city public schools. In what follows, I introduce readers to one of G:Class's projects that employed contemporary art to stimulate dialogue, understandings, and community engagement in relation to multiculturalism. In investigating this project, I assumed the role of an outside educator interested in using the resources available on the New Museum and G:Class's websites, as well as the two influential publications on multiculturalism and contemporary art that the museum published in 1996 and 2011. The project that I examine is the educational program developed for the 2009 Emory Douglas: Black Panther exhibition at the New Museum. This program generated critical dialogues between contemporary artists and participants, between participants and a local community, and between the participants themselves.

\section{Dialogues Between Students and Contemporary Artists}

The artwork of Emory Douglas is grounded in critical discourses in multiculturalism, and thus offers multiple entry-points for engagement with multicultural art education. Emory Douglas was an artist of the Black Panther Party ${ }^{44}$ and eventually became the Party's

\footnotetext{
43 PHILLIPS, Lisa and Toby Devan LEWIS. "Director's forward". In JOO, op. cit., p. x.

44 The Black Panther Party, which was in existence from 1966 to the early 1980 s, was a revolutionary socialist organization that was dedicated to working towards the elimination of police brutality against Black community members and the development of community social programs.
} 
Minister of Culture ${ }^{45}$. Douglas was responsible for the design and supervision of the layout and production of the Party's weekly newspaper, The Black Panther. He created an impressive amount of work in a wide variety of media. The New Museum described this production as utilizing "a straightforward graphic style and vocabulary of images that would become synonymous with the Party and the issues it fought for" ${ }^{46}$. The curator of the show, Sam Durant, viewed the exhibition as a retrospective of Douglas's prolific work, but also as a testament to how "art can encourage political consciousness and function within an activist context" ${ }^{47}$. Douglas's early images aimed to inspire and empower the Black community as they depicted "proud and defiant black men and women and trademark iconic caricatures of racist abusers of power" ${ }^{48}$. Later images show the positive results of the party's social programs including community regeneration, collectiveness, and economic development. As the New Museum has pointed out, Douglas's works are "dangerous pictures, and they were meant to change the world" The works are contentious and confrontational images intended to spark dialogue and community action. Their powerful messages to critique oppressive power, develop community empowerment, and engender positive social change, confront viewers in affective ways. Douglas's more recent works continue to engage with issues pertaining to race and social justice today.

In order to extend the conversation started within the museum's walls, the G:Class program collaborated with a group of 15 teenagers who were employed by the New York

45 New Museum: Digital Archive. Emory Douglas: Black Panther. <http://archive.newmuseum.org/index.php/Detail/ Occurrence/Show/occurrence_id/941> (retrieved in October, 2012).

46 Ibid.

47 New Museum. Press release for Emory Douglas: Black Panther. <http://archive.newmuseum.org/index.php/Detail/ Object/Show/object_id/6960> (retrieved in October, 2012).

48 Ibid.

49 Ibid.

50 New Museum, G:Class. Emory Douglas: What we want, what we believe mural project. $<$ http://www.gclass.org/in-action/emory-douglas-what-we-want-what-we-believe-muralproject> (retrieved in February 2013).
City Department of Youth and Community Development through the Summer Youth Employment Program ${ }^{50}$. Students worked directly with Emory Douglas, which offered opportunities for dialogue to evolve between this contemporary artist and these students. Douglas worked with these adolescents over the course of two weeks, discussing the history of the Black Panther Movement, conducting master printmaking workshops, and engaging in conversations with these participants ${ }^{51}$.

Additionally, students attended workshops led by artist educators at the New Museum and the Studio Museum in Harlem. During these workshops, they engaged in conversations focused on the social and political issues that were circulating at the time that Douglas created the work shown at the New Museum, including issues associated with the Black Panther Party and the connected Black Power Movement ${ }^{52}$. Throughout this process, students engaged in critical thinking, made art, and developed collaboration skills ${ }^{53}$.

The students and Douglas brainstormed ideas for the development of a city mural in collaboration with the New Museum, the Studio Museum, and artists Clare Herron and Chris Beck from the Groundswell Community Mural Project, which is a non-profit organization engaged in fostering public $\operatorname{art}^{54}$. The mural project was titled What We Want, What We Believe, and was to be inspired by Douglas's artwork. Douglas's images offer insight into the countercultures that grew out of the 1960s; by examining these images in relation to multicultural issues of today, they were employed as a catalyst, sparking conversations about

51 New Museum. Press release for Emory Douglas: Black Panther. <http://archive.newmuseum.org/index.php/Detail/Object/ Show/object_id/6960> (retrieved in October, 2012), p. 3. 52 New Museum, G:Class. Emory Douglas: What we want, what we believe mural project. <http://www.gclass.org/in-action/emory-douglas-what-we-want-what-we-believe-muralproject> (retrieved in February, 2013).

53 Ibid.

54 Ibid. 
issues pertinent to students' lives today. Desai, Hamlin, and Mattson refer to this potential for developing connections between the past and the present with contemporary art:

Talking about historical ideas through the lens of visual art can provide students with an avenue through which to address the emotional connections they have to the past, to develop an intellectual response to these connections, and to reimagine the idea of history as a personal journey ${ }^{55}$.

The New Museum and collaborating organizations offered these students opportunities to converse and learn with socially engaged artistic practitioners. In working with these artists, students developed connections between the issues of importance in these artists' work and the issues that are affecting their own lives and the lives of the community members that surround them. Stephen B. Carpenter II reminds us that when students work with pedagogical activities that highlight visiting artists' strengths and areas of expertise, "Students develop a better understanding of works of art, the ideas they convey, the concepts they explore, the people who create them, and the stories they tell" ${ }^{\prime 6}$. This information becomes meaningful in dialogic exchanges. Drawing on her research into the ways that contemporary artists perceive themselves as art creators and how this affects their pedagogical practices, Emily Pringle outlined that "artist educators function as facilitators enabling learners to engage directly with art works (which are seen to embody the knowledge of the artist creator and contribute actively to the construction of meaning), whilst sharing their knowledge through dialogic exchange" ${ }^{27}$. This dialogic exchange is a location for relationship

55 DESAI et al., op.cit., p. 10.

56 CARPENTER, Stephen B. II. "The stories of Flo Oy Wong: A look at a visiting artist workshop". Art Education. vol. 55, no. 1, 2002, pp. 17-23.

57 PRINGLE, Emily. "The artist-led pedagogic process in the contemporary art gallery: Developing a meaning making framework". International Journal of Art and Design Education. vol. 28, no. 2, 2009, pp. 174-182. formation, expression, skills acquisition, conceptual understanding, meaning making, identity exploration, and identity development.

\section{Dialogues Between Students and Local Communities}

In order to make significant connections between Douglas's work, their own ideas, and the community where the mural was to be located $\left(122^{\text {nd }}\right.$ Street and $3^{\text {rd }}$ Avenue, in East Harlem), students dialogued with the community's residents and workers to inquire into the matters that were important to this neighbourhood $^{58}$. There were a variety of topics that surfaced during these conversations, including gang violence, gentrification, healthcare, education, unemployment, and community collaboration $^{59}$. The students worked in collaboration with Emory Douglas and the artists from the Groundswell Community Mural Project, to explore ideas for the mural that would connect with the community, remaining sensitive to the neighbourhood's great diver$\operatorname{sity}^{60}$. This led to the creation of the theme, "Educate to Liberate" ${ }^{\text {61. }}$.

The initial connections that students developed with this community in Harlem were expanded upon while they created the mural over the summer of 2009. As the students developed the mural, residents and workers showed encouragement and appreciation for the work being conducted by the group, taking time out of their daily lives to engage in conversations with the students about the project ${ }^{62}$. Some community members offered suggestions, which inspired the students and artist-educators. A local store (H \& E Deli, Incorporated) even provided students with food as they worked $^{63}$. Through connecting with a theme that developed from and through this

58 New Museum, G:Class. Emory Douglas: What we want, what we believe mural project. <http://www.gclass.org/in-action/emory-douglas-what-we-want-what-we-believe-muralproject> (retrieved in February, 2013). 
community, the students, under the guidance of artist-educators, explicitly made "connections to lived experiences, places and communities", which clearly affected community members. ${ }^{64}$ A clip from NY1 news features a member of the Harlem community exclaiming, "It brings a light and a different glow to the community" ${ }^{65}$. Another member stated, "Everybody is enjoying [this effort]...it's from the heart" ${ }^{\prime 66}$.

By working with these community members in this way, students were engaging in a form of ethnography: a process of inquiry to represent and understand a culture ${ }^{67}$. When ethnography is employed in art education, students are encouraged to dialogue with community members and enable these dialogues to inform their artistic and social actions within their communities. With such approaches, students become active researchers: "Encouraging students to learn from people and places through collecting and interpreting objects, images, and oral histories resituates art rooms as sites for facilitating research as well as places for creative explorations" ${ }^{68}$. Dipti Desai elucidated that this method "provides an avenue for people in the students' communities to tell their life stories and thereby construct a more nuanced understanding of history, culture, and community" ${ }^{\prime 69}$. These young artists were influenced by the conversations they had with these community members and incorporated their ideas into the public mural they created. In this way, the art these students created "became a forum that opened public dialogue on issues of concern to the people" 70 . The public and political

64 CARPENTER, B. Stephen II et al., "Making a (visual/ visible) difference because people matter: Responsible artists and artistic responses to community". In. ANDERSON et al. (Eds.)., op. cit., p. 64.

65 Groundswell. What we want, what we believe. <http:// www.groundswellmural.org/project/what-we-want-what-webelieve $>$ (retrieved in February, 2013). [VIDEO].

66 Ibid.

67 DESAI, Dipti. "The ethnographic move in contemporary art: What does it mean for art education?". Studies in Art Education. vol. 43, no. 4, 2002, p. 307-323.

68 BEY, Sharif. "Excavating the cityscape through urban tales and local archives". Art Education. vol. 66, no. 4, 2013, p. 18. nature of this artwork naturally enables these community voices to continue to dialogue with passersby.

\section{Dialogues Between Students Through Collaborative Art Making}

In order to represent the chosen theme, "educate to liberate", in a meaningful way, the group decided to engage in a form of bricolage, mixing Douglas's images of past and present with their own representations ${ }^{71}$. This form of remixing visually speaks to the deep dialogue that developed between Douglas and the students over the course of the summer, as well as the dialogic relationship that formed between the students themselves. An interpretation of one of Douglas's well-known images, an immense profile of a man's face surrounded by rays, which represents knowledge pouring from the man's mind, appears on the left side of the mural (fig. 1 and fig. 2) ${ }^{72}$. Near the central portion of the mural, three children are shown walking into the distance, with the middle figure embracing the two outer figures (fig. 3). The three children appear to move into the future with a collective mindset. To the right of the three youth is a mother with her back turned to the audience, holding her infant child. A scale, which is typically associated with mythical representations of justice balancing truth and fairness, is shown dangling from the child's hand (fig. 4). The right side of the mural takes on a more overt declaration for action. Silhouettes of protestors are shown with picket signs, calling for positive change in the community. To their right is a large image of a young boy, presenting a newspaper to the

69 DESAI, Dipti. "The ethnographic move in contemporary art: What does it mean for art education?". Studies in Art Education. vol. 43, no. 4, 2002, p. 320.

70 Id., p. 309.

71 New Museum, G:Class. Emory Douglas: What we want, what we believe mural project. <http://www.gclass.org/in-action/emory-douglas-what-we-want-what-we-believe-muralproject> (retrieved in February, 2013).

72 Groundswell. What we want, what we believe. <http:// www.groundswellmural.org/project/what-we-want-what-webelieve> (retrieved in February, 2013). [VIDEO]. 




Figure 1

Emory Douglas, Hey Mister.

(c) 2014 Emory Douglas / Artists Rights Society (ARS),

New York

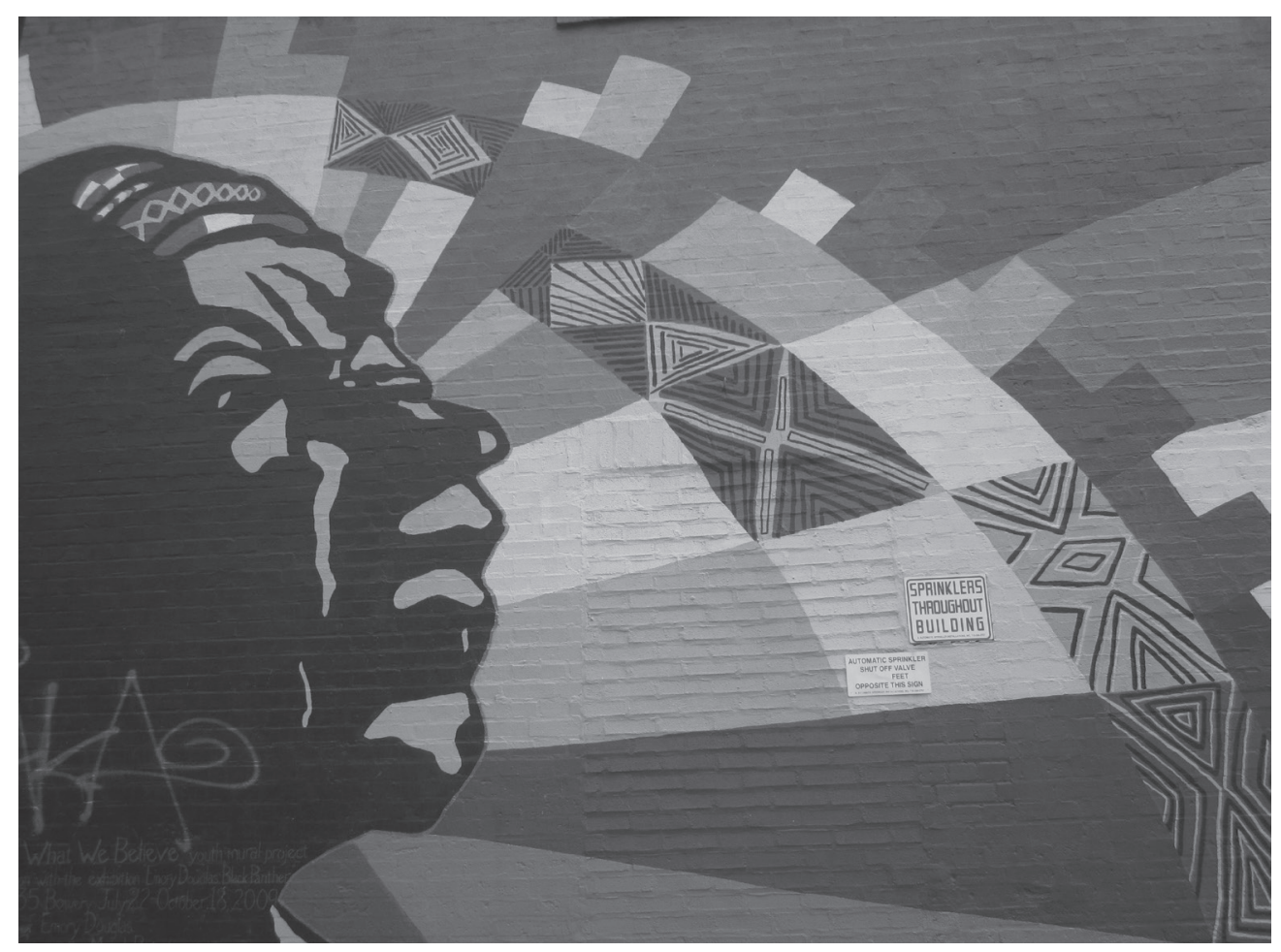

Figure 2

What We Want, What We Believe, 2009.

(c) The New Museum's G:Class Program \& Groundswell

Community Mural Project [Photographer: Natasha Reid] 


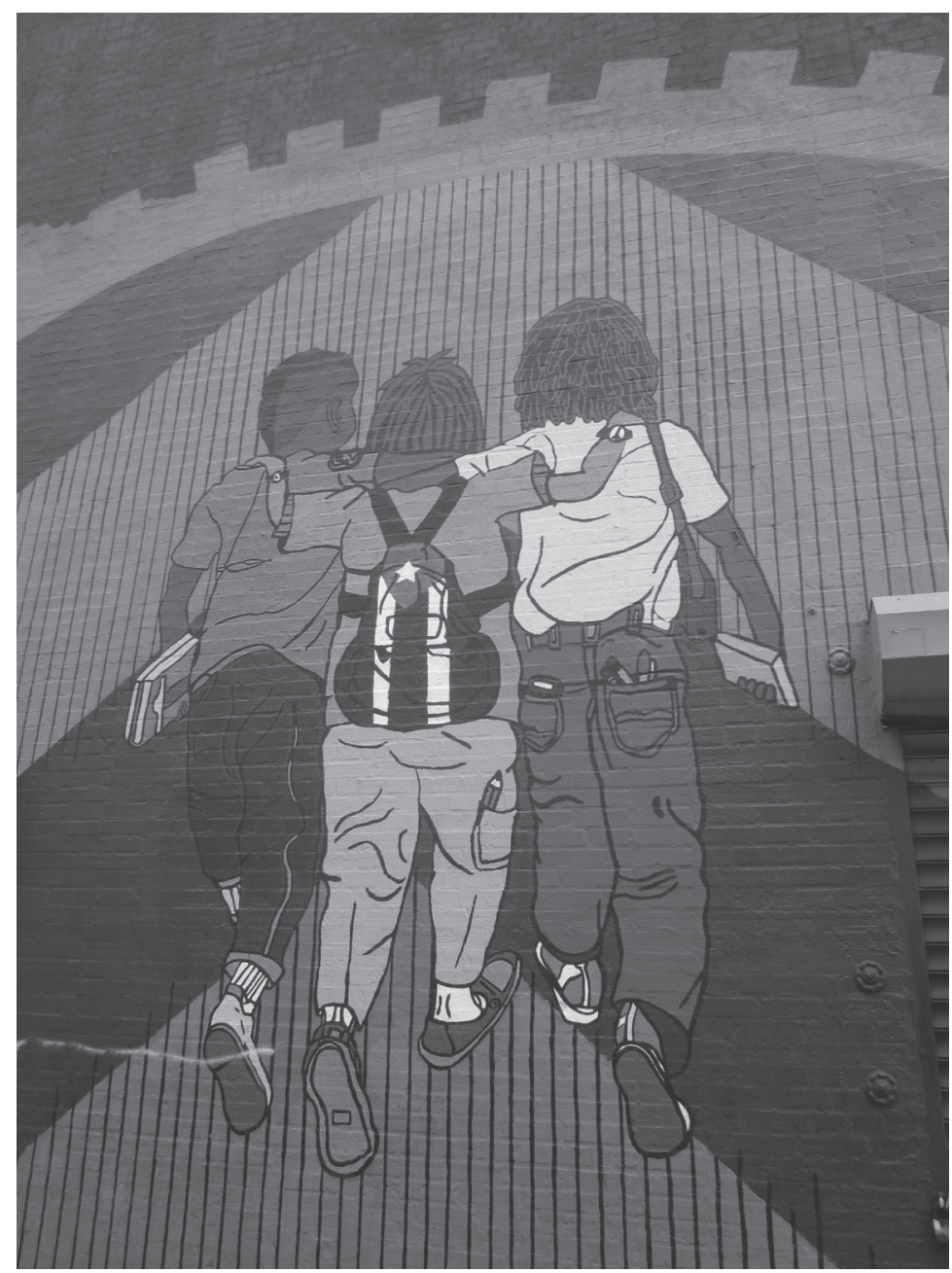

Figure 3

What We Want, What We Believe, 2009.

(C) The New Museum's G:Class Program \& Groundswell

Community Mural Project [Photographer: Natasha Reid]

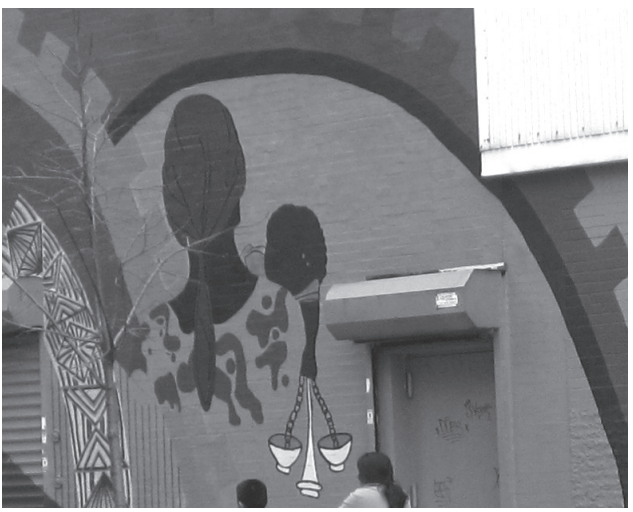

Figure 4

What We Want, What We Believe, 2009.

(C) The New Museum's G:Class Program \& Groundswell

Community Mural Project [Photographer: Natasha Reid] 
community, which reads "POWER TO THE PEOPLE. HARLEM UNITE” (fig. 5). This image clearly refers to another of Douglas's well-known works - a mural representation that was featured in the New Museum's exhibition of Douglas's work (fig. 6). The individual scenes work together to call for community involvement to provoke positive social change (fig. 7). Their message is one of hope, potential, and empowered action.

The students and team members must have participated in rich dialogues in order to decide upon aesthetic and content-related choices that would best represent their own perspectives and the issues that were revealed to be important to this community. Additionally, students collectively decided upon ways to connect their own aesthetic sensibilities with those of Emory Douglas. Tom Anderson highlighted the collaborative nature of community murals: "community murals emphasize group identity and cooperative problem solving" 73 . This is apparent in another community mural project: the Kids-Guernica Project, which has developed hundreds of peace murals with diverse community members. Takuya Kaneda and Hatto Fischer elucidated that the KidsGuernica Project "has the potential to open up people, including children and adults, by letting them learn through art to work together, and thereby realize a creative and cooperative human community" ${ }^{\text {"4 }}$. This sense of community is only possible through dialogic relationships. The young artists participating in the New Museum's What We Want, What We Believe project engaged in a similar process of artistic collaboration and dialogue in the development of their own social justice-oriented mural.

\section{Meaning Making and Change: Pillars of Multicultural Art Education}

Through critically engaging with an artist whose body of work is dedicated to examining a pivotal historical movement that questioned and dismantled oppressive power, through conversing with community members and contemporary artists, and through connecting these ideas to their own personal interests and those of community members, the participating adolescents were able to develop a personallyand socially-meaningful artistic production. They critically engaged with many of the multicultural, social justice-oriented concerns presented in Douglas's work and were able to pinpoint parallel contemporary issues particularly relevant to their own lives and to the lives of people in the neighbourhood where they were working. Through this, students engaged in efforts to elicit positive change within a community. In a NY1 news program, students referred to the meaningful connections they felt they made with this community and how they were able to contribute to this neighbourhood. One student stated, "I live in Brooklyn, but it feels good to go somewhere else and leave my mark there, to let them know that I actually care about the community and want to help out" ${ }^{75}$. Another said, "It is a great experience to be able to impact a community like this [and] to put something on the wall"76. These youth felt that they were able to engage in positive action within a community through socially engaged, dialogically oriented artistic production. Through engaging with critical multicultural programming, these adolescents participated in critical thinking, questioned standards of equality and justice, and became agents of potential change in this community ${ }^{77}$.
73 ANDERSON, Tom. "An introduction to art education for social justice”. In. ANDERSON et al. (Eds.)., op. cit., p. 7. 74 KANEDA, Takuya and Hatto FISCHER. "The Kids' Guernica peace mural project: A vehicle for social justice”. In. ANDERSON et al. (Eds.)., op. cit., p. 198.

75 Groundswell. What we want, what we believe. <http:// www.groundswellmural.org/project/what-we-want-what-webelieve $>$ (retrieved in February, 2013). [VIDEO]
76 Ibid.

77 CARPENTER, B. Stephen II et al., "Making a (visual/ visible) difference because people matter: Responsible artists and artistic responses to community”. In. ANDERSON et al. (Eds.)., op. cit., p. 64. 


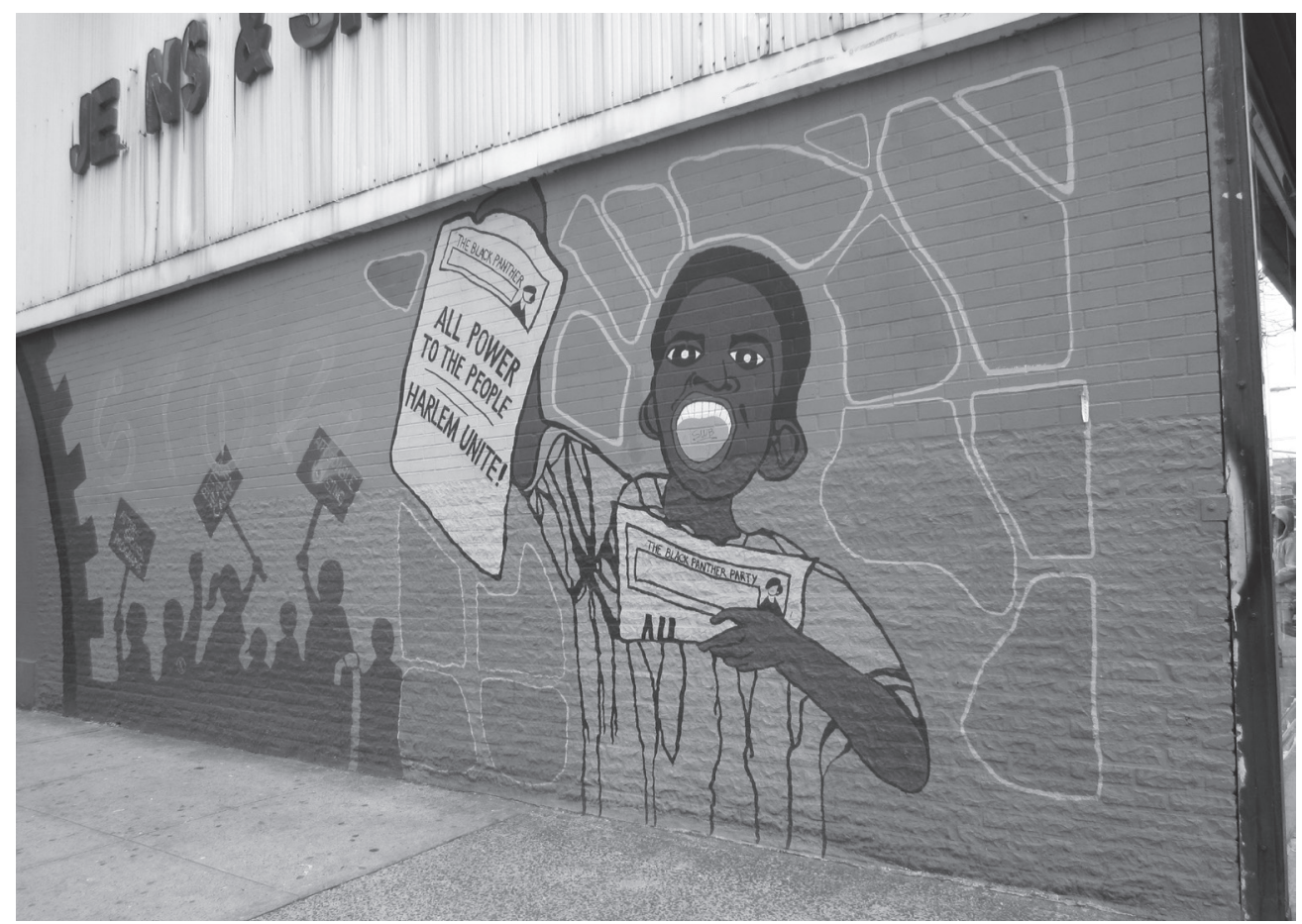

\section{Figure 5}

What We Want, What We Believe, 2009.

(c) The New Museum's G:Class Program \& Groundswell

Community Mural Project [Photographer: Natasha Reid]

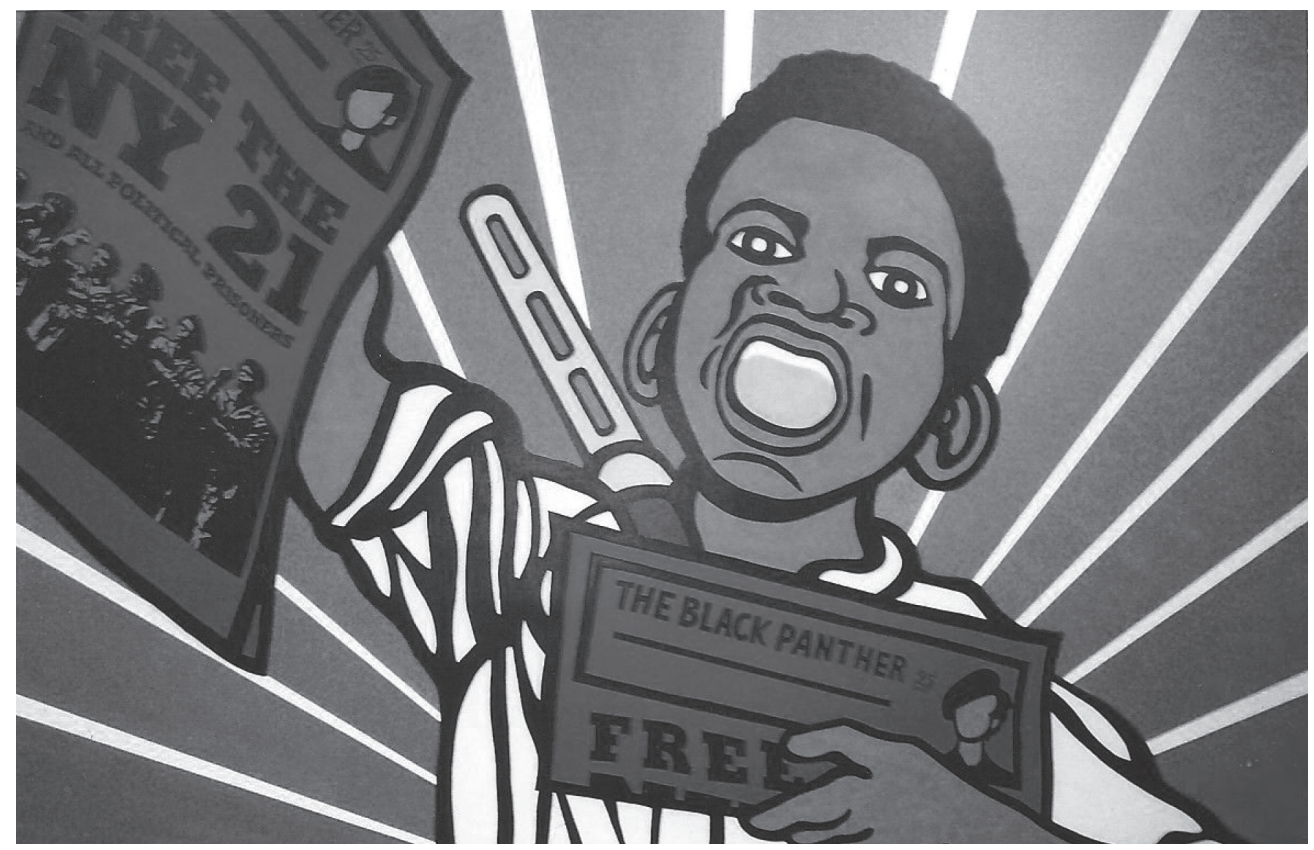

\section{Figure 6}

Emory Douglas, Free The NY 21.

(C) 2014 Emory Douglas / Artists Rights Society (ARS),

New York 


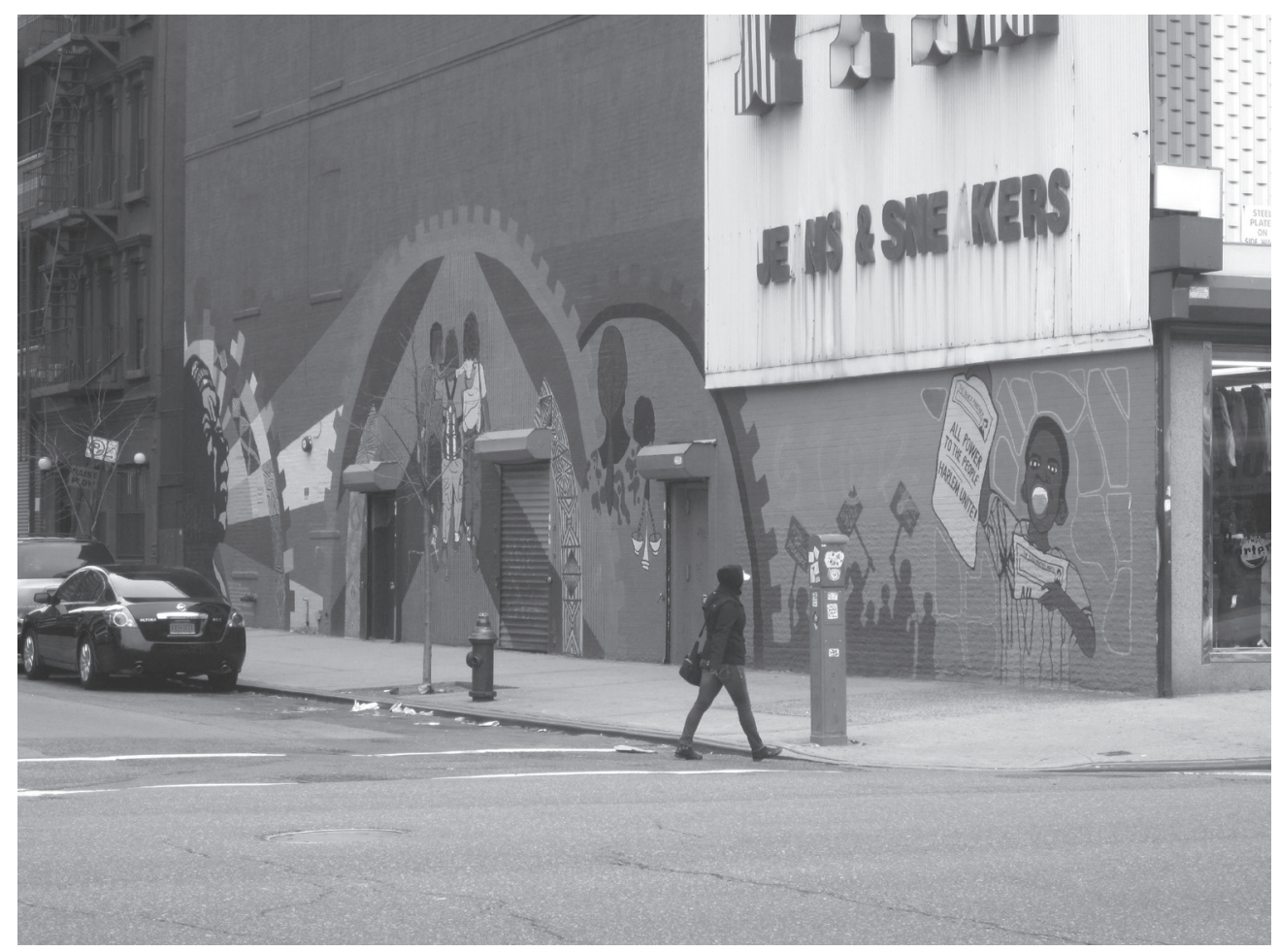

Figure 7

What We Want, What We Believe, 2009.

(c) The New Museum's G:Class Program \& Groundswell

Community Mural Project [Photographer: Natasha Reid] 
With the What We Want, What We Believe mural project, the G:Class program enabled contemporary art to become a conduit for conversation. Borders were crossed and new relationships developed, stemming from the initial interactions that began at the New Museum. This resulted in a community development art project that will continue to communicate with community members, inevitably sparking further dialogue. The New Museum moved beyond simply showcasing contemporary art focused on social justice concerns by engaging youth in a critical multicultural art education program.

Through dialogical exchanges, participants "create[d] something in common, something that [took] shape in their mutual discussions and actions" ${ }^{78}$. The What We Want, What We Believe mural project seems to have incorporated multiple discussions focused on both process and product, as well as encouraged the development of shared meaning making and community development. These are all essential components of critical multicultural education. At the centre of such discourses is the Bakhtinian notion of the dialogic, where we come to understand through complex, layered internal (individual) and external (social) forces $^{79}$. Such interchange is open-ended and essentially participatory, enabling multiple voices to enter the conversation and shape understandings ${ }^{80}$. It offers a liminal space for becoming and emerging, where there is a constant negotiation between the self and one's social communities. In this dialogic space, new understandings and, in the case of the G:Class's What We Want, What We Believe project, new artistic creations develop.

\section{Conclusions and Visions for the Future}

The New Museum provides us with an example of a contemporary art museum that is working with critically engaged multicultural education.

78 BOHM, David. On dialogue. London and New York: Routledge, 1996, p. 3.

79 BAKHTIN, Mikhail M. The dialogic imagination: Four essays. Austin, TX: University of Texas Press, 2006.; HOLLAND, Dorothy et al., Identity and agency in cultural worlds. Cambridge, MA: Harvard University Press, 2001.
Their G:Class program engages high school students with contemporary art practices as a means for supporting critical and creative thinking and envisioning possibilities for action and change. The What We Want, What We Believe mural project demonstrates one of the ways the G:Class program is achieving this. Through this program, students engaged in discussion-based encounters with contemporary artists, diverse community participants, and their own team members. Working in this dialogical way, students were able to produce an artwork that reflected history, the issues and aesthetics present in the mentoring artists' work, their own concerns, and those of the community where the mural is located. The program demonstrates an example of how contemporary art museums can fulfil community needs by becoming catalysts for stimulating interchange and action in relation to critical multicultural issues.

With the What We Want, What We Believe project, the New Museum engaged students and artists in critical dialogues focused on multicultural issues that are of both local and global importance and that draw on students' personal experiences. Past social justice issues, such as those pursued by the Black Panther Party, were compared and contrasted with contemporary issues pertinent to local communities. The youth developed themes for the mural in collaboration with members of the Harlem community where the mural is located. Students collaborated with each other and with various artists and community partners. Such actions inevitably required the development of a group identity and "cooperative problem solving”-important components of social justice efforts ${ }^{81}$. Thus the processes, including community dialogue and collaboration, were just as essential as the final product. Finally, these teenagers were viewed as artists and researchers resisting media representations of teenaged youth. Following this, I have

80 THORNTON, Alan. "Being an artist-teacher: A liberating identity?”. International Journal of Art and Design Education. vol. 30, no. 1, 2011, pp. 31-36.

81 ANDERSON, Tom. "An introduction to art education for social justice”. In. ANDERSON et al. (Eds.)., op. cit., p. 7. 
identified a series of strategies that were employed in the What We Want, What We Believe mural project, which can assist contemporary art museums to develop effective critical multicultural programming. These include:

- generating links between the local and the global and the past and the present; - facilitating dynamic conversations between students and diverse community members, including contemporary artists;

- confronting and discussing issues pertaining to multiculturalism through the lens of art and visual culture;

- grounding projects in participatory and experiential activities;

- establishing a safe space for critical inquiry;

- engaging students and other institutions in collaborative practices;

- ensuring that equal importance is given to processes and products;

- and valuing students (and other participants) as creative artists and researchers.

Interestingly, many of these strategies parallel contemporary artistic practices. Through employing such strategies in their educational programming, contemporary art museums can mirror the socially engaged and critical practices of many of the artists whose work they exhibit.

This article has demonstrated the importance of critical multiculturalism in art education and museum practices, including museum education; examined the turn towards issues pertaining to critical multiculturalism in many contemporary artists' work; and explored how one contemporary art museum is responding to these developments by utilizing contemporary art to trigger and sustain dialogues about social, political, and cultural issues. Through facilitating and provoking critical dialogues concerning social justice, equality, and difference across diverse communities via critical multicultural educational programs, contemporary art museums can become important initiators of positive change in our societies.
Contemporary art museums need to reflect the socially engaged nature of much of the work that they exhibit by boldly working with critical multicultural education in innovative ways. Through this, these public institutions will be positioned to become essential participants in generating critical dialogues in multiculturalism and fostering community action.

\section{Acknowledgements}

This research would not have come to fruition without the generous support of the Fonds de recherche du Québec - Société et culture. Natasha S. Reid would like to thank Jennifer Carter at the Université du Québec à Montreal and Dipti Desai at New York University for their crucial support throughout her postdoctoral research program. She would especially like to thank Jennifer Carter for her incredibly valuable assistance with the development of this article. Additionally, she would like to thank Jen Song and Michael Ano from the New Museum of Contemporary Art for greatly contributing to her understanding of the New Museum and its G:Class program. 
Natasha S. Reid, traduit par Micheline Giroux-Aubin et

Alessandra Mariani

\section{Enseigner les arts multiculturels par le biais de l'art contempo- rain : positionner le musée d'art contemporain comme leader de la production de dialogues critiques}

L'éducation multiculturelle est en expansion rapide et la quantité d'écrits liés à ce champ d'activité est impressionnante ${ }^{1}$. Les professeurs d'art qui utilisent les approches critiques de l'éducation multiculturelle analysent avec leurs étudiants les complexités associées aux groupes ethniques et à la culture ${ }^{2}$. Ces enseignants reconnaissent que les cours d'art peuvent et doivent offrir aux étudiants la possibilité de participer à des dialogues dynamiques, d'acquérir l'habilité de penser de façon critique, de s'engager dans une réflexion profonde, d'envisager des solutions créatives et de participer à l'activisme social. Ils considèrent l'art comme un outil de changement puissant et croient qu'un cours d'art doit être un lieu dynamique et politisé plutôt qu'un havre "neutre " et apolitique. Leur quête est stimulante en cette époque de tests normalisés, de ressources de plus en plus limitées, de diminution constante des cours d'arts visuels dans les établissements d'enseignement et de débats multiples centrés sur les arts et les problèmes sociaux.

Dans un tel climat, parce qu'ils sont des sites alternatifs d'apprentissage souvent considérés importants pour l'étude des cultures, les musées d'art peuvent devenir des ressources essentielles dans le cadre de l'enseignement de l'art multiculturel. Les musées cherchent à devenir de plus en plus des institutions socialement responsables en misant sur le dialogue, la recherche de sens, l'égalité, l'action et la transformation. À cet effet, plusieurs intègrent des approches pédagogiques critiques et examinent les structures de pouvoir, les multiples perspectives et possibilités d'interaction avec les visiteurs. De telles approches font appel au dialogue dynamique et voient le partage de récits comme des éléments essentiels du processus d'apprentissage.

Les musées d'art contemporain peuvent devenir des figures de proue dans la mise en place de ces efforts, si l'on considère que l'art contemporain peut être un outil dynamique et convaincant pour stimuler l'enseignement basé sur le dialogue, la critique et le multiculturalisme. Sur ce point, Susan E. Cahan et Zoya Kocur ${ }^{3}$ sont catégoriques: on

1 CAHAN, Susan E. et KOCUR, Zoya. Contemporary art and multicultural education. New York: The New Museum of Contemporary Art; Londres: Routledge, 1996; CAHAN, Susan E. et KOCUR, Zoya. "Contemporary art and multicultural education ». In. JOO, Eungie, KEEHN, Joseph II et HAM-ROBERTS, Jenny (dir.). Rethinking contemporary art and multicultural education. Londres: Routledge, en association avec The New Museum of Contemporary Art, 2011. 2 DESAI, Dipti. «Places to go: Challenges to multicultural art education in a global economy ". Studies in Art Education, vol. 46, no 4, 2005, p. 293-308.

3 CAHAN et KOCUR, "Contemporary Art and Multicultural Education ", op. cit. 
ne peut ignorer la pertinence de l'art contemporain dans l'éducation multiculturelle. Au cours des deux dernières décennies, un nombre croissant d'artistes et de critiques se sont penchés sur l'expression de Cornel West, "politique de la différence " ${ }^{4}$. Ce dernier décrit ces artistes et critiques comme des individus qui visent à « autonomiser et favoriser l'action sociale et, si possible, mettre à contribution une insurrection d'expansion de la liberté, de la démocratie et de l'individualité " ${ }^{5}$. Leur production artistique est connectée à la réalité quotidienne, elle baigne dans les discours critiques et vise ultimement à stimuler un changement positif. Ce type d'art peut devenir une plateforme puissante pour engager le dialogue, la recherche de sens, le débat, la construction des récits et l'action, tous des éléments importants des approches critiques de l'éducation multiculturelle. Donc, en raison de la nature du contenu artistique du musée d'art contemporain et du virage du milieu muséal vers des approches socialement responsables, le musée d'art contemporain est naturellement bien positionné pour devenir chef de file dans le domaine de l'enseignement des arts multiculturels et peut aider les éducateurs à l'affût de méthodes basées sur le dialogue et les approches critiques de l'enseignement des arts multiculturels.

Cet article traite de problèmes fondamentaux. Il questionne les facteurs sociaux, politiques, culturels et géographiques qui pourraient affecter le travail des enseignants d'art qui voudraient utiliser des approches multiculturelles critiques. Il tente de démontrer comment la programmation éducative dans les musées d'art contemporain peut refléter les approches multiculturelles basées sur le dialogue qui sont étudiées dans le domaine de l'enseignement de l'art et dans les pratiques artistiques contemporaines, et comment il est possible de soutenir ces approches et d'y contribuer. Pour répondre à ces questions, l'auteure étudie les actions d'une communauté aux prises avec un système éducatif aux ressources insuffisantes, mais liée à un certain nombre de musées d'art contemporain new-yorkais dont la mission et le programme éducatif se concentrent sur la diversité ainsi que sur des méthodes qui tiennent compte des différentes cultures. À l'aide d'une approche critique théorique basée sur les groupes ethniques et le contexte, l'auteure examine les tendances et les débats présents dans l'enseignement des arts multiculturels; les facteurs qui contribuent aux difficultés que doivent surmonter de nombreux enseignants d'art dans leurs efforts pour mettre en œuvre des approches multiculturelles critiques; le rôle potentiel que les musées d'art contemporain pourraient jouer pour aider ces enseignants; et la façon dont certains musées d'art contemporain font appel à une programmation multiculturelle avant-gardiste pour y parvenir.

\footnotetext{
$4 \quad I d .$, p. 9.

5 Traduction de: «empower and enable social action and, if possible, to enlist collective insurgency for the expansion of freedom, democracy, and individuality". WEST, Cornel. "The new cultural politics of difference ». In. FERGUSON, Russell, GEVER, Martha, MINH-HA, Trinh T., WEST, Cornel (dir.) et GONZALES-TORRES, Felix. Out there: Marginalization and contemporary cultures. New York: The New Museum of Contemporary Art and Massachusetts Institute of Technology, 1990, pp. 19-20.
} 